\title{
Rethinking governance for trade and health
}

\author{
The mechanism for dispute settlement in preferential trade agreements risks riding roughshod over \\ health
}

\author{
Helen Walls research fellow, Richard Smith professor \\ London School of Hygiene and Tropical Medicine and Leverhulme Centre for Integrative Research on Agriculture and Health, London, UK
}

Strengthening governance for more "healthy" trade is a recognised public health priority, ${ }^{1}$ and increasingly so given recent shifts in the international trade regime. ${ }^{2}$ After the second world war increasing trade liberalisation became a focus of international attention, and the General Agreement on Tariffs and Trade (GATT) was set up to coordinate international trade agreements. This was highly successful, and average world tariff rates fell from about $40 \%$ in 1948 to $4 \%$ in the early 1990 s. $^{3}$

At this time, GATT was replaced by the World Trade Organization (WTO), which had an increased scope. However, over the past two decades bilateral and regional trade agreements have proliferated. These have generally been negotiated in extreme secrecy, with increasingly "deep" commitments that go beyond those required by the WTO. ${ }^{2}{ }^{4}$ These commitments, the specifics of which have been well documented, ${ }^{25-7}$ have important implications for public health. One focus of concern is the investor-state dispute settlement (ISDS) mechanism, which allows foreign companies to sue host governments for compensation when policy changes threaten their ability to generate earnings from investments. ${ }^{8}$ Claims in investor-state disputes are adjudicated in private tribunals (unlike regular lawsuits in open court and the more transparent review processes for within state disputes under the WTO system) with no appeals process and without the consistency and learning from a system of precedents. ${ }^{5-11}$

This dispute settlement mechanism is proposed in two key preferential trade agreements currently under negotiation, the Trans Pacific Partnership (TPP), which involves 12 Asia-Pacific Rim countries, ${ }^{212}$ and the Transatlantic Trade and Investment Partnership (TTIP), between the European Union and United States. ${ }^{513}$ A salutary example of the public health implications of investor-state dispute settlements is the litigation in response to Australia's introduction of legislation for plain packaged cigarettes. ${ }^{10}{ }^{14}$ But the deep commitments have far ranging implications, including those relating to intellectual property, with potential for "evergreening" drug patents - that is, extending patents for slight changes to formulation without demonstration of superior benefit. ${ }^{215}$

Such provisions in modern preferential trade agreements shift the balance of policy making in favour of corporate interests, limiting policy options available to governments to protect public health, and making governments reluctant to legislate for public services because they fear lawsuits from foreign investors. $^{2516}$ This clearly challenges global, regional, and national governance structures concerned with health and healthcare.

To secure healthy trade, decision making processes need to include health as well as economic objectives, tackling trade in goods and services with direct negative effects on health. However, to date, much of the discussion and research regarding how to achieve such governance and what it would look like has been limited to the global level. For example, it has focused on institutions such as the WTO and World Health Organization. Governance of trade and health at global level is important, but the stalling of the WTO Doha Development Round and the proliferation of bilateral and regional preferential trade agreements with arguably greater public health risks emphasise the critical nature of governance at regional and national levels. ${ }^{217}$ Securing governance for healthy trade at these levels poses particular challenges. Some of them result from the different worldviews and large power imbalances between trade and health sectors, including the secrecy surrounding the negotiations and the vested corporate interests and well funded lobbies influencing countries' positions in the negotiations. ${ }^{11} 18$ Furthermore, developing the requisite regulatory capacities for the negotiation, implementation, and ongoing management of preferential trade agreements is expensive and skill intensive and requires considerable infrastructure. Poorer countries will especially struggle with this. ${ }^{17}$

Success requires the establishment of governance structures and mechanisms that bridge current sectoral divides. These structures and mechanisms must promote collaboration and build trust between trade and health communities. There are some, albeit limited, examples of this approach improving regional and national regulatory capacity. ${ }^{17}{ }^{19-22}$ In Brazil, for example, responsibility for the examination and granting of pharmaceutical patents has been split between the National Sanitary Surveillance Agency and the Brazilian patent office, giving more influence to a public health perspective. ${ }^{17}{ }^{23}$ Given scarce resources, it may be prudent for countries to focus on 
developing regulatory capacity in specific areas and then share best practice within regions, perhaps working towards developing regional regulatory mechanisms and structures. ${ }^{17}$ Specific goals may include stronger and more legally defensible health exceptions or exemptions in preferential trade agreements. ${ }^{11}{ }^{17}$ For example, Faunce has suggested that Australia should have negotiated health exemptions in mechanisms for investor-state dispute settlement with regard to plain packaging. ${ }^{10}$ Transparency in trade and investment policy making should also be prioritised. ${ }^{24}$

The rise of bilateral and regional trade initiatives, and concomitant reduction in influence of global institutions, makes more focus and research on governance at regional and national levels important, especially at the interface between these levels and global institutions and structure. Much of the existing research is not empirical and does not fully cover the characteristics of the issue and political environment. Public health researchers, practitioners, and policy makers must work together to understand and develop the necessary structures and mechanisms for governance at these levels. Without this, work on strengthening governance for healthy trade may be made less effective, or at worst irrelevant, by developments in bilateral and regional agreements.

Competing interests: We have read and understood BMJ policy on declaration of interests and declare that we have no competing interests. Provenance and peer review: Not commissioned; externally peer reviewed.

Lee K, Sridhar D, Patel M. Bridging the divide: global governance of trade and health. Lancet 2009;373:416-22.

2 Gleeson D, Friel S. Emerging threats to public health from regional trade agreements. Lancet 2013:381:1507-9.

3 Sanders L, Moulton K, Paggi M, Goodwin B. The GATT Uruguay round and the World Trade Organization: opportunities and impact for US agriculture. www.ces.ncsu.edu/depts/ agecon/trade/seven.htm

4 Friel S, Gleeson D, Thow A, et al. A new generation of trade policy: potential risks to diet-related health from the Trans Pacific Partnership agreement. Global Health 2013:9:46.
5 Bennet N. Health concerns raised over EU-US trade deal. Lancet 2014;384:843-4.

6 Thow AM, Snowdon W, Labonté R, et al. Will the next generation of preferential trade and investment agreements undermine prevention of noncommunicable diseases? A prospective policy analysis of the Trans Pacific Partnership Agreement. Health Policy 2015119:88-96.

7 Monasterio E, Gleeson D. Pharmaceutical industry behaviour and the Trans Pacific Partnership Agreement. N Z Med J 2014;127:6-12.

8 Provost C, Kennard M. The obscure legal system that lets corporations sue countries. Guardian 2015 Jun 10. www.theguardian.com/business/2015/jun/10/obscure-legal-systemlets-corportations-sue-states-ttip-icsid.

9 Reynolds L, McKee M. Is the NHS really safe from international trade agreements? BMJ 2015;350:h2179.

10 Faunce T. Plain packaging in a broader regulatory framework: preventing false claims and investor-state lobbying. In: Mitchell A, Voon T, Liberman J, eds. Public health and plain packaging of cigarettes: legal issues. Edward Elgar, 2012:200-13.

11 Walls $\mathrm{H}$, Baker P, Smith R. Moving towards policy coherence in health and trade. J Public Health Policy (forthcoming).

12 Gornall J. New Pacific trade deal—good for pharma, bad for public health. BMJ 2015;351:h3649.

13 Hilary J. The Transatlantic Trade and Investment Partnership and UK healthcare. BMJ 2014;349:g6552.

14 Jarman H. Attack on Australia: Tobacco industry challenges to plain packaging. J Public Health Policy 2013;34:375-87.

15 Vines T, Crow K, Faunce T. Balancing public health, trade and intellectual monopoly privileges: recent Australian IP legislation and the TPPA. J Law Med 2012;20:280-94

16 Davies P. Trade secrets: will an EU-US treaty enable US big business to gain a foothold? BMJ 2013;346:f3574.

17 Walls $\mathrm{H}, \mathrm{Smith} \mathrm{R}$, Drahos P. Improving regulatory capacity to manage risks associated with trade agreements. Global Health 2015;11:14.

18 Corporate Europe Observatory. Who lobbies most on TTIP? 2014. http://corporateeurope. org/international-trade/2014/07/who-lobbies-most-ttip.

19 Thaiprayoon S, Smith R. Capacity building for global health diplomacy: Thailand's experience of trade and health. Health Policy Plan 2014 Oct 21. [Epub ahead of print.]

20 WHO Country Office for Thailand. International trade and health programme: framework on strategic development towards policy coherence between international trade and health. WHO, 2011.

21 Smith RD, Lee K, Drager N. Trade and health: an agenda for action. Lancet 2009;373:768-73

22 Baker P, Kay A, Walls $\mathrm{H}$. Strengthening trade and health governance capacities to address non-communicable diseases in Asia: challenges and ways forward. Asia Pacific Policy Stud 2015;2:310-23.

23 Drahos P. Global governance of knowledge: patent offices and their clients. Cambridge University Press, 2010.

24 Freeman J, Keating G, Monasterio E, et al. Call for transparency in new generation trade deals. Lancet 2015;385:604-5.

Cite this as: BMJ 2015;351:h3652

(c) BMJ Publishing Group Ltd 2015 